\title{
Frequency and enzymatic activity (proteinase and phospholipase) of Candida albicans from edentulous patients, with and without denture stomatitis
}

\section{Freqüência e atividade enzimática (proteinase e fosfolipase) de Candida albicans de pacientes desdentados totais, com e sem estomatite protética}

\author{
Sibele Sarti PENHA* \\ Esther Goldenberg BIRMAN** \\ Fernando Ricardo Xavier da SILVEIRA*** \\ Claudete Rodrigues de PAULA****
}
PENHA, S. S.; BIRMAN, E. G.; SILVEIRA, F. R. X. da; PAULA, C. R. de. Frequency and enzymatic activity (proteinase and phospholipase) of Candida albicans from edentulous patients, with and without denture stomatitis. Pesq Odont Bras, v. 14, n. 2, p. 119-122, abr./jun. 2000.

\begin{abstract}
The so called erithematous stomatitis is frequently observed in denture wearers, being local factors, mainly related to the presence of yeasts, considered important for its development. Having these aspects in mind, we evaluated edentulous patients with and without denture stomatitis (DS), identifying the yeasts obtained from the palate, and determining the relative level of the proteinase and phospholipase exo-enzymes produced by $C$. albicans. The results suggested that $C$. albicans was the most frequent species observed, being more prevalent in patients presenting DS, isolated or in association with other yeasts, with high expression of proteinase.
\end{abstract}

UNITERMS: Candida albicans; Denture stomatitis; Proteinase; Phospholipase.

\section{INTRODUCTION}

Denture stomatitis (DS) comprises superficial tissue alterations, mainly under the base of upper prostheses, representing inflammatory reactions of the mucosae ${ }^{3}$. These lesions are commonly associated with the presence of complete dentures, presenting diffuse or punctuated erithematous areas, besides other unspecific aspects mainly observed on the palate. Soft tissue alterations are sometimes associated with angular cheilitis, glossitis, and burning sensation, although a great number of patients do not refer any symptom ${ }^{1,17}$.

The aetiology of DS is not yet well understood, being associated with local factors such as poor oral hygiene and mechanical trauma mainly caused by inadequate conditions of the prosthesis, as well as the presence of microbial agents. The commonly related microorganisms are yeasts of

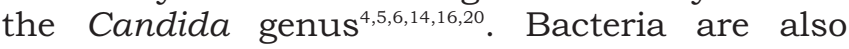

reported as casual agents of these lesions, identified in general as Gram-positive $\operatorname{cocci}^{7,9}$.

Differences between the oral flora from patients with and without prosthetic stomatitis have not been observed, but the plaque index and the frequency of yeasts are higher in the first group, although their specific role is not yet well established ${ }^{7}$.

Virulence factors, like proteinase and phospholipase produced by $C$. albicans, have been also evaluated ${ }^{12,15}$, since they are prone to facilitate adhesion, conditioning a more pathogenic activity ${ }^{3,13}$. These enzymes are capable of invading tissues, leading to dysfunction or even rupture of cellular membranes, and to a higher grade of adherence and colonization ${ }^{2,8,12,15}$.

BUDTZ-JORGENSEN ${ }^{3}$, comparing C. albicans samples from patients with and without prosthetic stomatitis, suggested that the pathogenicity of the yeasts could be related to the enzymatic activity,

\footnotetext{
* Assistant Professor; ** Professor and Chair; *** Associate Professor - Department of Stomatology, School of Dentistry, University of São Paulo.

**** Professor, Department of Microbiology, Biomedical Sciences Institute, University of São Paulo.
} 
PENHA, S. S.; BIRMAN, E. G.; SILVEIRA, F. R. X. da; PAULA, C. R. de. Frequency and enzymatic activity (proteinase and phospholipase) of Candida albicans from edentulous patients, with and without denture stomatitis. Pesq Odont Bras, v. 14, n. 2, p. 119-122, abr./jun. 2000 .

even when an association between the proteolytic activity in vitro and the severity of the lesions has not been observed ${ }^{3}$. Proteinase production can also interfere in the pathogenic potentiality of bacterial components of plaque through cleavage of salivary antibacterial immunoglobulins ${ }^{18}$. Having all these aspects in mind, the aim of this study was to assess edentulous patients, with and without DS, evaluating the frequency and species of yeasts related to both groups, as well as the proteinase and phospholipase levels.

\section{MATERIAL AND METHODS}

From 120 patients from the School of Dentistry, University São Paulo, 69 were selected for this study, being the main inclusion factor, the edentulous maxilla. Patients of both genders varying from the $3^{\text {rd }}$ to the $8^{\text {th }}$ decade of age (mean age: 59.23 years; standard deviation: + 13.91) were selected. From all patients, 49 were denture wearers presenting DS on the palate, while 20 were totally edentulous patients without DS. A specific protocol was utilized considering age, previous and present medical history, as well as other information like time of denture usage, frequency of oral and prosthesis hygiene and reported symptoms. Extra- and intra-oral examinations were performed.

Using sterile swabs, samples for the mycological test were collected from the hard palate, and immediately inoculated on plates of Sabouraud dextrose agar* with $100 \mu \mathrm{g} / \mathrm{ml}$ of chloramphenicol**. Incubation was made at $25^{\circ} \mathrm{C}$, up to 15 days. Colonies suspect of being Candida spp were subcultured on the slant and maintained at $25^{\circ} \mathrm{C}$, with successive replications until identifica- tion. The colonies were identified according to the methodology described by KREGER-VAN RIJ ${ }^{10}$ and submitted to enzyme production assays.

The study of proteinase was carried out based on RUCHEL et $a .^{17}$, and the study of phospholipase, on PRICE et al. ${ }^{15,16}$ and WILLIAMSON et al. ${ }^{20}$, being the lecture performed after 72 hours. The samples producing enzymes presented an opaque zone of precipitation around the yeast inoculation point, being the enzymatic activity obtained by measuring the colony diameter and dividing it by the diameter plus the precipitation zone $\left(\mathrm{P}_{z}\right)$. In both cases, when $\mathrm{P}_{z}$ was 1.00 , the enzymatic activity was zero. Between 0.64 and 0.99 , this activity was considered positive; when lower than 0.64, it confirmed a strong positivity.

\section{RESULTS}

From sixty-nine patients, $62.3 \%$ (43) presented positivity for yeasts. In the group with DS, $75.5 \%$ $(37 / 49)$ of the patients had yeasts isolated, being $81,1 \%$ of the samples $(30 / 37)$ identified as Candida albicans. In seven patients, it was possible to identify C. parapsilosis, Geotrichum candidum, C. tropicalis, C. guilliermondii, and C. lusitaniae associated with C. albicans, besides other isolated species such as C. parapsilosis, $C$. tropicalis and C. glabrata (Graphic 1).

The collected material from the group without lesions demonstrated that eight samples were positive for yeasts, corresponding to $40 \%(8 / 20)$. C. albicans was identified in 37.5\% (3/8); C. krusei, in $25 \%(2 / 8)$; C. glabrata, in $12.5 \%(1 / 8)$, and also associations such as C. tropicalis and C. glabrata; C. parapsilosis and C. glabrata, each one in different samples (Graphic 2) .

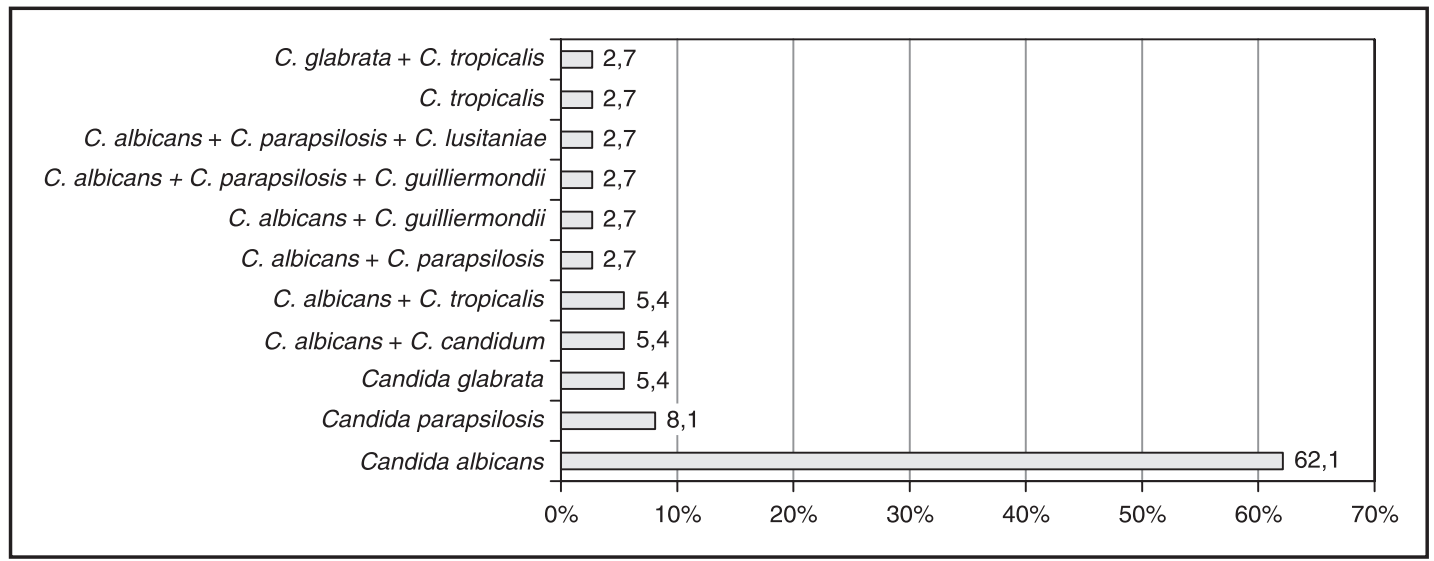

* Difco.

** Chloromicetin - Parke Davis.
GRAPHIC 1 -

Frequency of yeasts in patients with denture stomatitis. 
PENHA, S. S.; BIRMAN, E. G.; SILVEIRA, F. R. X. da; PAULA, C. R. de. Frequency and enzymatic activity (proteinase and phospholipase) of Candida albicans from edentulous patients, with and without denture stomatitis. Pesq Odont Bras, v. 14, n. 2, p. 119-122, abr./jun. 2000 .

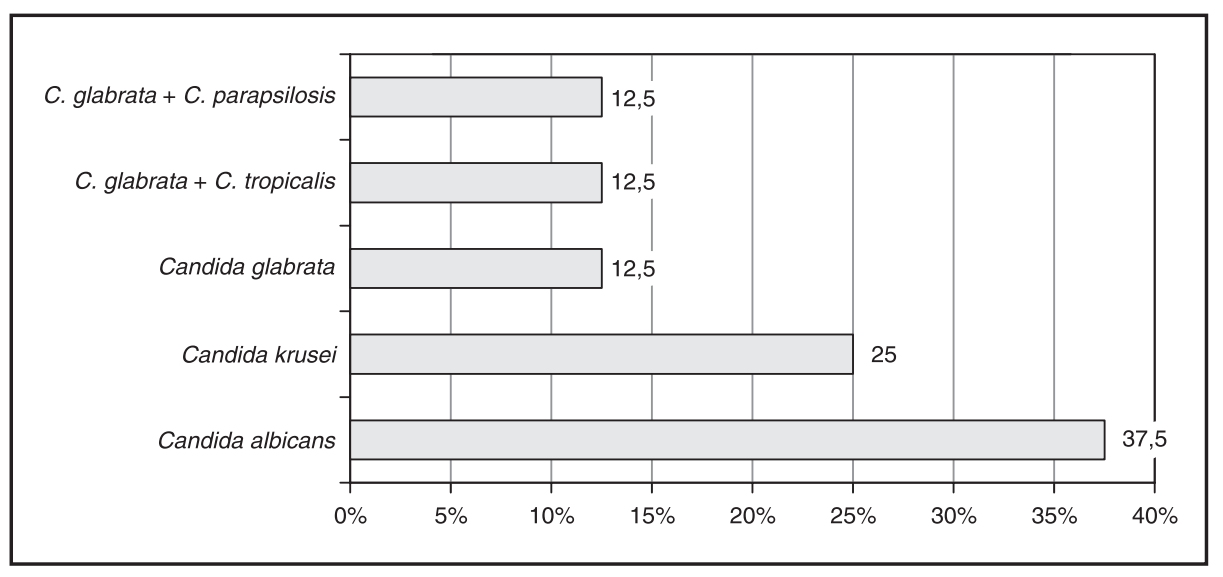

GRAPHIC 2 - Frequency of yeasts in patients without denture stomatitis.
The enzymatic evaluation demonstrated that $100 \%(30 / 30)$ of C. albicans colonies produced proteinase, presenting a strong positivity. The enzymatic production of phospholipase was present in $83.3 \%(25 / 30)$ of the samples, with a strong positivity in $36.6 \%$ of them.

\section{DISCUSSION AND CONCLUSION}

The aetiology of DS is dependent on varied factors, including the usage of dentures and the association with yeasts as well as with bacteria, besides the presence of microtraumas and poor oral hygiene. The establishment of this condition is mainly related to the involvement of yeasts. An adequate diagnosis is important to prevent more aggressive or diffuse candidosis, when other predisposing systemic factors are present $t^{6,12,18}$.

A higher frequency of isolation of yeasts in patients presenting DS has already been observed ${ }^{6,12}$ and it was confirmed in this study, which revealed positivity for yeasts in $75.5 \%$ of the sample.

Various species of yeasts were identified. The $C$. albicans species corresponded to $62.1 \%$ of the yeasts isolated from the patients with DS. Identification of more than one species per clinical sample was observed in relation to C. albicans, C. glabrata and $C$. tropicalis, as quoted by VANDENBUSSHE; SWINNE ${ }^{19}$.

In our results, eight different associated species were identified, similarly to the results of KREHER et al. ${ }^{11}$, that reported $27 \%$ of associations in their sample.

Isolation of yeasts was also positive in edentulous patients without DS. C. albicans, C. krusei, C. glabrata and C. tropicalis were identified in association with C. glabrata, which are results similar to those of BUDTZ-JORGENSEN ${ }^{6}$, although $C$. tropicalis and C. guilliermondii were not observed, suggesting that a variability of species can occur also in totally edentulous patients without DS.

In relation to the enzymatic activity of $C$. albicans, we have to consider the high level of proteinase production in $100 \%$ of them. BUDTZ-JORGENSEN ${ }^{3}$ did not find a positive correlation between the in vitro proteolytic activity and the severity of the lesion. Since they used different techniques from the ones employed in this study, it is difficult to establish comparisons. The high level of proteinase production suggests that this enzyme can play a role in the establishment and maintenance of DS. More investigations are necessary to help to understand the relationship between its action in the mucosae and its possible influence on the clinical aspects of DS.

Differently from proteinase, phospholipase presented a low or intermediate level of production, not suggesting a defined activity related to the clinical aspects observed.

So, C. albicans was the most frequent yeast in complete denture wearers presenting DS, compared with patients without DS. Associations of yeasts could be observed, including different species. The proteinase from $C$. albicans presented a high level of positive production, differently from phospholipase.

Candidosis is still undefined in some aspects, although it is frequently observed in denture patients. The presence of yeasts and their enzymatic activity need to be further investigated. 
PENHA, S. S.; BIRMAN, E. G.; SILVEIRA, F. R. X. da; PAULA, C. R. de. Frequency and enzymatic activity (proteinase and phospholipase) of Candida albicans from edentulous patients, with and without denture stomatitis. Pesq Odont Bras, v. 14, n. 2, p. 119-122, abr./jun. 2000.

PENHA, S. S.; BIRMAN, E. G.; SILVEIRA, F. R. X. da; PAULA, C. R. de. Frequência e atividade enzimática (proteinase e fosfolipase) de Candida albicans de pacientes desdentados totais, com e sem estomatite protética. Pesq Odont Bras, v. 14, n. 2, p. 119-122, abr./jun. 2000.

A Estomatite Protética (EP) é freqüentemente observada em pacientes portadores de prótese total, sendo a presença de fungos considerada um importante fator para o seu aparecimento. Baseado neste fato, avaliamos pacientes edêntulos com e sem estomatite protética, identificando os fungos presentes, e os níveis de proteinase e fosfolipase produzidos por Candida albicans. Os resultados mostraram que C. albicans foi a espécie mais freqüente, prevalecendo em pacientes com EP. Todas as cepas de C. albicans isoladas foram fortemente positivas para proteinase, diferentemente da atividade de fosfolipase.

UNITERMOS: Candida albicans; Estomatite sob prótese; Proteinase; Fosfolipase.

\section{BIBLIOGRAPHIC REFERENCES}

1. ALLEN, C. Diagnosing and managing oral candidosis. $\mathbf{J}$ Am Dent Assoc, v. 123, p. 77-82, 1992.

2. BORG, M.; RUCHEL R. Expression of extracellular acid proteinase by proteolytic Candida $s p$. during experimental infection of oral mucosa. Infect Immun, v. 56, p. 626-631, 1988.

3. BUDTZ-JORGENSEN, E. Proteolytic activity of Candida spp. as related to the pathogenesis of denture stomatitis. Sabouraudia, v. 12, p. 266-271, 1971.

4. BUDTZ-JORGENSEN, E. Etiology, pathogenesis, therapy, and prophylaxis of oral yeast infections. Acta Odontol Scand, v. 48, p. 61-69, 1990.

5. BUDTZ-JORGENSEN, E.; BERTRAM, V. Denture stomatitis I. The etiology in relation to trauma and infection. Acta Odontol Scand, v. 28, p. 71-92, 1970.

6. BUDTZ-JORGENSEN, E.; STENDERUP, A.; GRABOWSKI, M. An epidemiologic study of yeasts in elderly denture wearers. Community Dent Oral Epidemiol, v. 3, p. 115-119, 1975.

7. BUDTZ-JORGENSEN, E.; THEILADE, E.; THEILADE, J. Quantitative relationship between yeasts and bacteria in denture-induced stomatitis. Scand J Dent Res, v. 91, p. 2134-2142, 1983.

8. GHANNOUM, M., ELTEEN, K. A. Correlative relationship between proteinase production, adherence and pathogenicity of various strains of Candida albicans. J Med Vet Mycol, v. 24, p. 407-413, 1986.

9. KOOPMANS, A. S. F.; KIPPUW, N.; GRAAFF, J. Bacteria in denture-induced stomatitis. J Dent Res, v. 67, p. 1246-1250, 1988.
10. KREGER-VAN RIJ, N. J. W. The yeasts: a taxonomic study. Amsterdam, Elsevier, 1984.

11. KREHER, J. M.; GRASER, G. N.; HANDELMAN, S. L.; EISENBERG, A. D. Oral yeasts, mucosal health, and drug use in an elderly denture wearing population. Spec Care Dentist, v. 11, p. 222-226, 1991.

12. ODDS, F. C. Candida and candidosis. London, Bailliere Tyndall, 1988,468 p.

13. OLSEN, I. Oral adhesion of yeasts. Acta Odontol Scand, v. 48, p. 445-453, 1990.

14. PENHA, S. S.; BIRMAN, E. G.; SILVEIRA, F. R. X.; PAULA, C. R. Ocurrence of yeast in the mouth of denture wearers. J Dent Res, v. 75, p. 1104, 1996.

15. PRICE, M. F.; CAWSON, R. A. Phospholipase activity in Candida albicans. Sabouraudia, v. 15, p. 179-185, 1977.

16. PRICE, M. F.; WILKINSON, I. D.; GENTRY, L. O. Plate method for detection of phospholipase activity in Candida albicans. Sabouraudia, v. 20, p. 7-14, 1982.

17. RUCHEL, R.; TEGELER, R.; TROST, M. A comparison of secretory proteinases from different strains of Candida albicans. Sabouraudia, v. 20, p. 233-244, 1982.

18. SAMARANAYAKE, I.; MACFARLANE, T. W. Oral candidosis. London; Buttherworth \& Co, Ltd, 1990, $265 \mathrm{p}$.

19. VANDENBUSSCHE, M.; SWINNE, D. Yeast oral carriage in denture wearers. Mykosen, v. 27, p. 431-435, 1984.

20. WILLIAMSON, M. I.; SAMARANAYAKE, L. P.; Mac FARLANE T. W. Phospholipase activity as a criterion for biotyping Candida albicans. J Med Vet Mycol, v. 24, p. 415-417, 1986. 